Available Online at http://journal.unismuh.ac.id/index.php/otoritas

Otoritas : Jurnal Ilmu Pemerintahan, 8 (1), April 2018, 56-64

\title{
The Implementation of Minimum Service Standards (MMS) on Public Service for Health Services Sector in Bondowoso, Indonesia
}

\author{
Untung Kuzairi*), Hary Yuswadi, Agus Budihardjo, Himawan Bayu Patriadi \\ Postgraduate School of Administration Studies, Faculty of Social and Political Sciences,Universitas \\ Jember, Jln. Kalimantan No. 37, Kab. Jember, Jawa Timur 68121, Indonesia.
}

Received: 7 November 2017; Revised: 6 January 2018; Accepted: 23 February 2018

\begin{abstract}
One of heatlh policies implemented by the hospital is the minimum service standards (MSS). MSS is a benchmark of hospital service quality in providing services to the public. Talking about health service quality problem, it was found out as the field fact that the achievement of MSS indicator in General Hospital of Dr. H. Koesnadi Bondowoso, Indonesia in 2016 still did not fulfill target of standard hospital service (type B) and minimum service standard (MSS) of hospital. This fact shows that the quality of health services in general hospital of dr. H. Koesnadi Bondowoso is still low. So, this research aims to describe the policy implementation of minimum service standard and to analyze the obstacles in the implementation of MSS policy at general hospital of dr. H. Koesnadi Bondowoso. So, this research would discuss the policy implementation of minimum service standards by using Edward III concept as a tool to analyze it. This research employed qualitative research with phenomenological approach. The results showed that the implementation of MSS policy of $d r$. H. Koesnadi Bondowoso general hospital still did not run well. This was due to several factors such as communication, bureaucratic structure, sources, dispositions (attitude) and leadership in sectoral ego control. Sectoral ego can be shaped from educational background of specialist doctors who still adhered seniority and lack of individual role of implementor in building interpersonal communication and conflict management.
\end{abstract}

Keywords: Hospital; Minimum Service Standards; Policy Implementation; Sectoral Ego

How to Cite: Kuzairi, U., Yuswadi, H., Budihardjo, A., \& Patriadi, H. B. (2018). The Implementation of Minimum Service Standards (MMS) on Public Service for Health Services Sector in Bondowoso, Indonesia. Otoritas : Jurnal Ilmu Pemerintahan, 8(1), 56-64.

Permalink/DOI: https://doi.org/10.26618/ojip.v8i1.939

${ }^{*}$ Corresponding Author.

E-Mail : untung.kuzairi@gmail.com

Copyright (C) 2018, Otoritas : Jurnal Ilmu Pemerintahan, ISSN: 2088-3706 (Print), ISSN: 2502-9320 (Online) 
Available Online at http://journal.unismuh.ac.id/index.php/otoritas

Otoritas : Jurnal Ilmu Pemerintahan, 8 (1), April, 2018, 57

\section{INTRODUCTION}

The 1945 Constitution of the Republic of Indonesia The article $28 \mathrm{H}$ and the constitution of WHO 1948 state that health is a fundamental right of every citizen. The statement is supported by Law number 23 of 1992 on health which states that health is a right for all Indonesian citizens. Therefore, the government plays a pivotal role in fulfilling the fundamental rights for all Indonesian citizens. One of the goals of Indonesia National Development in the field of health is to provide optimal, qualified, and comprehensive health services to all levels of society. The development of health services is a part of the development of public services.

Public policy differs markedly from public service. In this case, Sinambela et al. (2011) argues that public service is defined as an effort to give service to the needs of the person or community that has interests in the organization in accordance with the basic rules and procedures has been established. On the other hand, the definition of public policy is an act that has a purpose to be determined by an actor or a number of actors in overcoming a problem or a case (Anderson, 2004). Thus, public policy is needed to address social problems including public service issues. Meanwhile, public service itself is the implemetation of the policies that has been made.

Public policy concerning public services must have obstacles in its implementation. According to Edwards III, the influential factors in the implementation of public policy involve communication, resources, disposition (attitude), and bureaucratic structure (Subarsono, 2011). Edwards III discusses three important communication processes within a policy, namely transition, consistency, and clarity. Furthermore, the resource component includes the number of staff and the expertise of the actor, relevant and sufficient information to implement policies, powers that guarantee policies that can be directed as expected, and supporting facilities that can be used to carry out program activities (buildings, funds, and other facilities and infrastructure). Meanwhile, for disposition, there are three forms of attitude or response of actor toward the policy, such as awareness of actor, instructions or direction of the actor to respond policies toward acceptance or rejection and intensity of the response. Then, the bureaucracy as the executor must be able to support the politicallydecided policy by doing good coordination and spreading the responsibility (fragmentation) on the established policy.

The hospital is a concrete manifestation of the public service that is obliged to provide services without distinguishing social status to all levels of society. The development of technology and information as well as changes in government policy on the structure of health services financing in Indonesia also contributed to the public orientation towards health services. The Government policy is implemented through the National Health Insurance begun in 2014. Changes in the pattern of health services in Indonesia have an impact on financing of health services for the majority of underprivileged and independent society. Changes in the pattern of health services is the impetus to force hospitals to improve services and facilities with the aim that patients who visit the hospital feel satisfied and become loyal so that the continuity of hospital services run all the time.

The quality of health services is always related to the level of patient's satisfaction in hospital, maternal and infant mortality rate, and occupancy rate or Bed Occupancy Ratio (BOR) of hospital. The three indicators of health service quality that occurred in the hospital are interrelated (Sutoto, 2009). The obligation to notice service quality is strengthened by Handayani (2012) who states that the core of service is to maintain quality as- 
surance. In addition, Sutoto (2009) stated that the quality of service is a series of health service activities based on standard and proper medical procedures so that the quality of health services will be maintained, viewed from the perpectives of the health service providers and patient satisfaction.

Talking about health service quality problem, the fact informed that in 2016, the General Hospital of Dr. H. Koesnadi Bondowoso has experienced an imbalance between indicators of Standard hospital (type B) service guidelines and hospital minimum service standards (MSS). The indicators are well-documented in the 2016 Hospital annual book report which showed that: $47.05 \%$ of nonstandard hospital facilities and infrastructure are supposed to be met by noneducational type $\mathrm{B}$ hospitals; the availability of basic medical specialists (pediatric specialists, internist, and obstetrics and surgical specialists) are inappropriate for existing standard (there is only $42 \%$ of human resources or only 7 out of 12 need basic specialist); hospital occupancy rate (HOR) is inefficient (it only reaches $56,42 \%$ with the standard of $60-85 \%)$, the average of Community Satisfaction Index (SCI) is still low (it only fulfills $78.74 \%$ with $90 \%$ standard); and Infant Mortality Rate (IMR) is still high (43 per 1,000 live births with a standard of $\leq 24$ per 1,000 live births).

In addition, the evaluation report of Minimum Service Standards (MSS) of dr. $\mathrm{H}$. Koesnadi general hospital Bondowoso in 2016 showed that there were still 14 types of services that did not meet the Minimum Service Standard of Hospital covering emergency services (there are 2 indicators that have not fulfilled MSS), outpatient unit (there is 1 indicator that has not fulfilled MSS), inpatient unit (4 indicators that have not fulfilled MSS), surgery unit (there is 1 indicator that has not fulfilled the MSS), labor and perinatology unit (there are 2 indicators that have not fulfilled MSS), intensive unit (there is 1 indicator that has not met MSS), radiology unit (there are 2 indicators that have not met MSS), pharmacy unit (there are 2 indicator that has not fulfilled MSS), blood transfusion unit (there is 1 indicator that has not fulfilled MSS), laundry unit (there is 1 indicator that has not fulfilled MSS), administration and management unit (there are 2 indicators that have not fulfilled MSS , maintenance of hospital facilities unit (there is 1 indicator that has not fulfilled MSS), infection prevention and control unit (there is 1 indicator that has not fulfilled MSS), and nutritioin unit (there is 1 indicator that has not fulfilled MSS).

These facts show that the quality of health services in dr. H. Koesnadi Bondowoso general hospital is still low and it is reasonable to assume that the low quality of service is due to the implementation of the policy of Minimum Service Standard of Hospital which did not run well. As according to Hogwood and Gunn, who state that any policy of its form actually carries the risk of failure (Wahab, 2008). Usually the policy that has a risk of failure is caused by the following factors: bad execution (bad implementation), bad policy or bad luck (policy which is a bad luck). Therefore, the study purpose for describing the implementation of policy Minimum Service Standards in dr. $\mathrm{H}$. Koesnadi Bondowoso general hospital, and analyzing the inhibiting factors of it that caused the low quality of health service in dr. H. Koesnadi Bondowoso general hospital.

This research would discuss the policy implementation of minimum service standards by using Edward III concept as a tool to analyze it. As previous studies on policy implementation using Edward III theory such as those have been done by Nurani (2009), Sukowati (2013), Saputra \& Suranto (2016), Kusnadi (2015), and Matto (2016). However, no one gone further with the factors affecting the policy 
Available Online at http://journal.unismuh.ac.id/index.php/otoritas

Otoritas : Jurnal Ilmu Pemerintahan, 8 (1), April, 2018, 59

implementation of the minimum service standards and largely explains only the variables of Edward III theory which include communication, sources, disposition and bureaucratic structure. In addition, although previous research has investigated more closely the factors affecting policy implementation such as that of Aneta (2010), but the focus of the study was different from this research. Beside factors based on Edward III theory, this study will also explore about leadership factors in controlling aspects of sectoral ego in the policy implementation of minimum service standards at the hospital. The existence of leadership factors that will be studied, will be a distinguishing factor with previous research that is expected to contribute for the successful implementation of public policy in the future.

\section{RESEARCH METHODS}

This research was conducted in general hospital of dr. H. Koesnadi Bondowoso. This research employed qualitative method of phenomenological approach. The method of recruiting informants used in this research is purposive sampling (conditional sample). The informants were determined and adapted to the theme of the study. Researchers chose informants who knew the problem well, directly involved with the problem, and were willing to reveal the problem. The requirements of the informants were: a) the informants directly involved in the implementation of the MSS of hospital policy and had a working experience for more than 9 years so that it is possible to explain the implementation of MSS policy and the influencing factors that cause low quality of health services; and b) the informants who wanted to obviously and honestly explain about the implementation of SPM policy and the influencing factors that cause low quality of health services. The informant includes individuals who are documented as hospital and medical policy makers (who are in management position) at the level of room, installation and medical unit or highly influential medical personnel in the eyes of their friends, professional and medical organization leaders (doctors and dentists) in the hospital. Then, the number of informants is not restricted and adapted to the role and involvement of the informants that are considered important with clear and realistic reason and become key informant.

Primary data collection in this research is done by in-depth interview method through guided interview as the basic material of interview. During the indepth interviews, the researchers also conducted a direct observation to assist and complete richer data collection. In addition, Focuss Group Discussion (FGD) discussion was also conducted. While the secondary data collection is done by studying document. The data obtained then analyzed. Data analysis model used in this research is interactive data analysis technique that consists of data collection, data presentation, data reduction, data verification and data conclusions. Furthermore, the validity and reliability of data used in this study was triangulation method. This study employed three kinds of triangulation, namely triangulation of data, triangulation between researchers, and triangulation methodology.

\section{RESULTS AND DISCUSSION}

Grounded in the Edward III theory which includes communication, sources, bureaucratic structure and disposition, the implementation of MSS policy in general hospital of dr. H. Koesnadi Bondowoso can be expressed as follows, first, the findings of research on the aspects of communication in the implementation of MSS policy has not been noticed in detail because MSS is only used as reporting material. It shows that the MSS policy has not been communicated and socialized effectively so that the policy is under- 
stood as report material only. In addition, there is an unharmonious relationship between the structural part as the administration service providers and the functional part as medical service providers, whereas the two parts are actors (organizer) of MSS hospital policy. This is because the communication is not well established among policy actors.

As Guzley's research states that work clarity, work participation between subordinates and superiors is determined by work commitments built through communication (Liliweri, 2014). So, if communication is not well established it will be difficult in building work commitments.

The second is the sources. Based on the results of the documentation study, it was found that there is a shortage of personnel in some types of services such as pharmacy, nutrition, laundry, and radiology unit. In addition, the quality of human resources is also low in some types of services: lack of D3 (diploma degree) in nurse who is very skilled in intensive care unit (ICU) which is evidenced by the certificate, and lack of trained human resources in prevention and control service of infection. In addition, there is a lack of funds for the implementation of training activities for human resources in hospitals. Furthermore,facilities and infrastructure are inadequate, especially on medical supporting equipment. As the research conducted by Saputra \& Suranto (2016), stated that the lack of resources greatly affects the lack of optimal implementation of minimum service standards in the field of referral services in Baubau city public hospitals, although the communication, disposition and bureaucratic structure have been met well. Therefore, the fulfillment of resource needs is very important to be done to achieve the success of policy implementation.

The third is bureaucratic structure. The findings of research on the aspects of bureaucratic structure showed the lack of coordination from various parties in the hospital. The existence of gap between a specialist with a nurse can be interpreted that the coordination and cooperation between them is still poor. Lack of coordination and cooperation can show that the bureaucratic structure in this hospital is not conducive yet indeed the bureaucratic structure demands the cooperation with stakeholders including doctors and nurses in this hospital. The absence of good cooperation between doctors and nurses can lead to health services provided to patients does not run smoothly so that the implementation of MSS policy does not work optimally either. Than, there was a shifting of personnel from one unit to another with no obvious reason suggests that showed the bureaucratic structure in the hospital is less conducive due to the lack of coordination among stakeholders in the hospital. Edward III in Winarno (2008) pointed out that the nature of the bureaucratic structure that influences the implementation of the policy is fragmentation, namely the dissemination of the responsibility of a policy to several different bodies requiring coordination from various circles. Therefore, a conducive bureaucratic structure demands coordination from various stakeholders. So that, lack of coordination can impact on less optimal implementation of minimum service standard policies.

The fourth is the aspect of the diposition or attitude of the policy actor. The findings indicated that the policy actor's attitude often acts on his or her own desire, especially the actor of the policy on medical services (specialists) such as they come for visiting the patients regardless of the service schedule. Therefore, the attitude of the policy actors has not supported the implementation of MSS policy of the hospital.

Based on the above description, it indicated that the implementation of MSS policy in general hospital of dr. $\mathrm{H}$. Koesnadi Bondowoso was still not optimal. In addition to these four aspects of 
policy implementation as stated by Edward III above, the results of research has also shown another finding that is the leadership in sectoral ego control for the implementation of MSS policy. These aspects can be seen from the existence of problems related to the resignation of a specialist because of the needs of medical equipment and distrust between specialist and the director. The character of the specialist who tend to have high demands, do not want to understand the condition of the hospital and behave arbitrarily is very closely related to the the place of their education in which medical support equipment they need is completely available and they only use them. Such arbitrary attitude can disrupt the implementation of MSS hospital's policy. In addition, based on the results of discussions through Focuss Group Discussion (FGD), it can be stated that both of the units in the hospital have the same power (bargaining posisition) that both have interests and have certain goals as well. This can lead to disagreements that disrupt the relationship between units in the hospital. Impaired relationships continue to peak to uncertain service by employees and delayed service received by patients in the hospital.

Sectoral ego can be formed from educational background on PPDS system that still follow seniority. The stillfrequent seniority in specialist education with ruling attitudes by senior specialists and should always be adhered by junior specialist, eventually such perceptions will be brought to the workplace or hospital when the junior specialist completes the PPDS. Therefore, the specialist tend to put forward his will. Beside that, sectoral ego also can be because the MSS policy actors (implementor) have not been able to build good interpersonal relationships. This can be seen from several specialists (as the actor of MSS hospital policy) who have not been able to establish good relationships with the nurses, as well as prob- lems between the director and the specialists who tend to drag on and there has been no efforts to solve it. As the opinion of Warshawsky, Havens \& Knafl (2014) who state that interpersonal relationships between nurses with peers and doctors support the performance of nurses. Interpersonal communication can be one effort that can be done not only to build a good relationship but also to solve particular problems that exist in the hospital. Problems that cannot be solved through formal relationship approach can be overcomed through non-formal relationship approach that is through good interpersonal communication. Than, implementor also have not been able to manage conflict well. Conflict is an element that cannot be separated in organizational life including hospital organization, then the conflict must be managed so that it does not interfere the service provided. For this reason, Cinar \& Kaban (2012) argue that conflict management is conducted to operate the organization effectively and efficiently. Therefore, it becomes one of the leaders' tasks in building interpersonal relationships and improving conflict management skills from subordinates.

Furthermore, the director as a leader in the hospital has not yet applied a supportive leadership style. As Mosadeghrad (2014) argues that supportive leadership can improve the quality of health services. Suwanto (2011) states that this supportive leadership style is friendly and shows care that a leader also needs subordinates and vice versa. In fact, it was found that directors rarely come to the field to see the performance of medical personnel directly, lack of communication with their subordinates, lack of attention as well as comprehension towards the needs and problems of subordinates so that some specialist submit resignation because they considers the policies of the director were not in line with what he wants. Therefore, the leadership style of the director has not been able to suppress 
the existence of sectoral ego, especially among medical personnels. It can be possible when the director can apply a supportive leadership style that can minimize the emergence of sectoral ego indicated by a specialist so that the characters formed during the education of a specialist can be suppressed.

In addition, organizational culture in hospitals has not been conducive. This can be seen from the application of the 7 culture (welcoming, greetings, smiles, courteous, courteous, wholehearted and patient) which were only applied at certain time such as the demand of accreditation, then fades when the demands are over. As Hsi-Chi et. al (2012) showed that organizational culture gives a sense of identity, hope, and rules that help the organization achieve its goals. Therefore, the role of leader is very necessary in implementing organizational culture that can guide subordinates in doing the job. In addition, there has been no special effort from the leader (director) in fostering employees motivation to always carry out the job as good as possible.

Beside that, the leadership still can not integret employees and the interests of the hospital. In accordance with these, Hasibuan (2009) states that to obtain attitudes and behavior of employees in accordance with the desired company then it should affect the physical and spiritual needs. In other words, the leader should strive to provide fair and reasonable remuneration and treat the employees as well as human beings. As Herzberg suggests, the best way to motivate employees is to incorporate elements of challenge and opportunity to achieve success in their work (Hasibuan, 2009). Beside it, Alderfer suggests that leaders should challenge by rewarding hardworking employees more than others so that employees are motivated to achieve the rewards. This is because humans want to be trully respected and recognized (Usman, 2009). So, through the rewards, employees are motivated to work hard in achieving organizational goals. Similarly, the implementation of Minimum Service Standards of hospital, the directors should give awards for units that successfully provide services in accordance with MSS hospital so that employees in other units whose service is still low in accordance with MSS hospital can also be motivated to provide services in accordance with the MSS hospital. In line with this, Joanna (2014) states that employees who are motivated to improve the productivity of each organization will ultimately assist the organization in achieving its goals.

\section{CONCLUSION}

The implementation of MSS policy at dr. H. Koesnadi Bondowoso general hospital did not work smoothly. This is because of the following factors: communication, resources, bureaucratic structures, dispositions and leadership in sectoral ego control. The facts found that there was disharmony between implementor of policies caused by the lack of good communication so that minimum service policy standards have not been considered in detail by the implementor and only used as a report material only. In addition, there is also a lack of quantity and quality of human resources in some service units and lack of facilities and infrastructure both from medical equipment and general operational equipment so that the impact on the lack of smooth implementation of minimum service standard policies. Furthermore, the attitude of the implementor is less supportive of the implementation of the policy because there are some implementors less than the maximum in the hours of service visit.

Then, there was also a weakness of coordination between implementors caused by less conducive bureaucratic structure and attitudes of specialist doctors who are less than maximal in the hours of service visit, thus causing the achievement of the minimum service 
Available Online at http://journal.unismuh.ac.id/index.php/otoritas

Otoritas : Jurnal Ilmu Pemerintahan, 8 (1), April, 2018, 63

standard indicator is less than optimal. While the leadership of the director as the leader of the hospital has not reflected the effective leadership behavior because the director rarely interacts with his subordinates so as to lack communication and intepersonal relationships, lack of understanding and satisfy the needs of his subordinates and had not been able to build collective consciousness from his subordinates in creating an organizational culture that supports the policy implementation of minimum service standards. Therefore, sectoral ego in the implementation of minimum service standard policies still can not be controlled by the effective leadership.

\section{ACKNOWLEDGEMENT}

The authors grateful to our colleagues in Universitas Jember and Hospital of Dr. H. Koesnadi Bondowoso,Indonesia.

\section{REFERENCES}

Anderson, J. A. (1975). Public policymaking: basic concepts in political science. New York: Praeger University Series.

Aneta, A. (2012). Implementasi Kebijakan Program Penanggulangan Kemiskinan Perkotaan (P2KP) Di Kota Gorontalo. Jurnal Ilmiah Ilmu Administrasi Publik, 1(1), 54-65.

Çınar, F., \& Kaban, A. (2012). Conflict management and visionary leadership: An application in hospital organizations. Procedia-Social and Behavioral Sciences, 58, 197-206.

Handayani, F. (2012). Manajemen Mutu Rs. Swasta. Available from: (https:// www.academia.edu/8707779/ manajemen_mutu_rs_swasta).

Hasibuan, M. (2009). Manajemen Sumber Daya Manusia. Jakarta: PT. Bumi Aksara.
Hsi-Chi, et al. (2013). The Influence of Hospital Organizational Culture On Organizational Commitment Among Nursing Executives. African Journal of Business Management, 6(44), pp. 10888-10895.

Joanna, R. S. (2014). Employee's Motivation At Hospital As A Factor Of The Organizational Success. Human Resources Management \& Ergonomics, 8(2).

Kusnadi, D. (2015). The Influence of Policy Implementation From The Change of Institutional Status Toward Quality of Patient Service in Hospital. International Journal of Scientific \& Technology Research, 4 (10).

Liliweri, A. (2014). Sosiologi dan Komunikasi Organisasi. Jakarta: Bumi Aksara.

Matto, R. (2016). Implementasi Kebijakan Standar Pelayanan Minimal (SPM) Bidang Lingkungan Hidup Di Kabupaten Nunukan (Doctoral dissertation, Universitas Terbuka).

Mosadeghrad, A. M. (2014). Factors influencing healthcare service quality. International journal of health policy and management, 3(2), 77.

Nurani, D. (2009). Analisis implementasi program Bantuan Operasional Sekolah (BOS) pada Sekolah Dasar Negeri di Kota Jakarta Selatan (Doctoral dissertation, Universitas Indonesia. Fakultas Ilmu Sosial dan Ilmu Politik).

Saputra, D. R., \& Suranto, S. (2016). Implementasi Standar Pelayanan Minimal Bidang Kesehatan Di RSUD Kota Baubau. Journal of Governance and Public Policy, 1(2).

Sinambela, et al. (2011). Reformasi Pelayanan Publik: Teori, Kebijakan, dan Implementasi. Jakarta: PT Bumi Aksara. 
Available Online at http://journal.unismuh.ac.id/index.php/otoritas

Otoritas : Jurnal Ilmu Pemerintahan, 8 (1), April, 2018, 64

Subarsono, AG. (2011). Analisis Kebijakan

Publik (Konsep, Teori dan Aplikasi). Yogyakarta: Pustaka Pelajar.

Sukowati, N. P. (2013). Implementasi Kebijakan Pelayanan Kesehatan Masyarakat Miskin Non Kuota (Jaminan Kesehatan Daerah Dan Surat Pernyataan Miskin)(Studi Di Dinas Kesehatan Kabupaten Blitar). Jurnal Administrasi Publik, 1(6), 1195-1202.

Sutoto, S. (2009). Mutu Pelayanan Dalam Pedoman Akreditasi Rumah Sakit. Jakarta: Kementerian Kesehatan Republik Indonesia.

Suwanto, S. (2011). Asas-asas Manajemen Sumber Daya Manusia. Bandung: Suci Press.

Usman, H. (2009). Motivasi Dalam Bekerja Karyawan. Jakarta: PT. Gramedia
Widiasarana Indonesia

Wahab, S. A. (2008). Analisis Kebijakan: Dari Formulasi ke Implementasi Kebijakan Negara. Edisi Kedua. Jakarta: Bumi Aksara.

Warshawsky, N. E., Havens, D. S., \& Knafl, G. (2012). The influence of interpersonal relationships on nurse managers' work engagement and proactive work behavior. The Journal of nursing administration, 42(9), 418

Winarno, B. (2008). Kebijakan Publik: Teori dan Proses. Yogyakarta: Media Pressindo. 